Penelitian

\title{
Morfometri Ovarium setelah Pemberian Ekstrak Daun Kelor (Moringa oleifera LAM)
}

\section{Ovarian Morphometry after Giving Moringa oleifera LAM Leaf Extract}

\author{
Musthamin Balumbi ${ }^{*}$, Fachruddin², Muhammad Risman ${ }^{3}$ \\ 'Staf Pengajar Pendidikan Biologi, Fakultas Keguruan dan Ilmu Pendidikan, Universitas Halu Oleo, Kendari \\ ${ }^{2}$ Staf Pengajar Biologi, Fakultas Sains dan Teknologi, Institut Teknologi dan Kesehatan Avicenna, Kendari \\ ${ }^{3}$ Laboran Laboratorium Pengembangan Unit Biologi, Universitas Halu Oleo, Kendari \\ *Penulis untuk korespondensi: musthaminbalumbi@uho.ac.id \\ Diterima 20 September 2020, Disetujui 17 Januari 2021
}

\begin{abstract}
ABSTRAK
Ovarium merupakan organ reproduksi utama dalam sistem reproduksi betina yang berperan dalam menghasilkan sel ovum. Kualitas folikel yang dihasilkan ovarium dipengaruhi oleh nutrisi yang dikonsumsi suatu individu. Kelor (Moringa oleifera LAM) telah lama dikenal sebagai tanaman dengan kandungan nutrisi yang cukup tinggi. Nutrisi yang terdapat di dalam kelor adalah vitamin, mineral, antioksidan, asam amino esensial dan senyawa fitosterol. Kandungan nutrisi pada kelor paling banyak ditemukan di daun. Penelitian ini bertujuan untuk mengetahui kualitas ovarium setelah pemberian ekstrak daun kelor (Moringa oleifera LAM). Metode yang digunakan adalah penelitian eksperimental. Hewan yang digunakan dalam penelitian ini adalah 60 ekor mencit betina (Mus musculus) umur 14-15 minggu dengan rerata bobot badan 30-35 g. Ekstrak daun kelor yang diberikan dengan dosis $0 \mathrm{mg} \mathrm{kg}^{-1} \mathrm{BB}, 300 \mathrm{mg} \mathrm{kg}^{-1} \mathrm{BB}, 400 \mathrm{mg} \mathrm{kg}^{-1} \mathrm{BB}, 500 \mathrm{mg} \mathrm{kg}^{-1}$ BB. Pengamatan dilakukan setelah pemberian $5,10,15,24$, dan 34 hari. Parameter penelitian meliputi siklus estrus dan morfometri ovarium. Hasil Penelitian menunjukkan bahwa tingkat konsentrasi dan lamanya pemberian ekstrak daun kelor memberi pengaruh terhadap panjang, lebar, dan bobot ovarium mencit. Konfirmasi siklus estrus bertujuan untuk mengetahui bahwa siklus reproduksi dalam ovarium mencit berlangsung normal. Siklus estrus pada mencit penelitian rata-rata berlangsung normal, yakni terjadi selama 4-5 hari.
\end{abstract}

Kata kunci: ekstrak daun Moringa oleifera LAM, morfometri ovarium, Mus musculus

\begin{abstract}
Ovaries are the main reproductive organs female reproductive system. Ovaries have an important function in producing oocyte. In the ovaries, the quality of the follicles produced is influenced by the nutrients an individual consumes. Moringa oleifera LAM has long been known as a plant with high nutrient. The nutrients found in moringa were vitamins, minerals, antioxidants, essential amino acids and phytosterol compounds. The most nutritional content in moringa is found in leaves. This study aims to determine the quality of the ovaries after giving Moringa oleifera LAM leaf extract. The method used is experimental research. The animals used in this study were 60 female mice (Mus musculus) aged 14-15 weeks with an average body weight of 30-35 g. Moringa leaf extract given at a dose of o mg kg-1 BW, $300 \mathrm{mg} \mathrm{kg-1} \mathrm{BW,} 400 \mathrm{mg}$ kg-1 BW, $500 \mathrm{mg}$ kg-1 BW. Observations were made after 5, 10, 15, 24, and 34 days of administration. Each observation was taken three mice from each treatment to observe ovarian morphometry. The research parameters included the estrous cycle and ovarian morphometry. The results showed that the concentration level and duration of application of Moringa leaf extract had an effect on the length, width and weight of the mice ovaries. The confirmation of the estrous cycle is part of a study that aims to determine that the reproductive cycle in the ovaries of mice is normal. On average, the estrous cycle in the research mice was normal, which occurred for 4-5 days.

Keywords: leaf extract of Moringa oleifera LAM, ovarian morphometry, Mus musculus
\end{abstract}




\section{PENDAHULUAN}

Ovarium adalah salah satu organ reproduksi yang sangat penting. Fungsi ovarium diantaranya memertahankan jumlah corpus luteum, menghasilkan oosit dan hormon-hormon reproduksi pada betina (Balumbi et al., 2019). Optimalisasi fungsi ovarium dicapai dengan meningkatnya jumlah folikel yang didukung oleh morfologi ovarium yang baik (Gannon et al., 2012; Gannon et al., 2013; Ramadhani et al., 2017). Nutrisi merupakan salah satu faktor penting yang memengaruhi pertumbuhan dan perkembangan folikel serta morfometri ovarium (ChavattePalmer et al., 2014; Ramadhani et al., 2017).

Kelor (Moringa oleifera LAM) merupakan tanaman yang kaya nutrisi, seperti vitamin, mineral, antioksidan, asam amino esensial dan senyawa fitosterol (Jusnita \& Syurya, 2019, Nurulita et al., 2019, Utary et al., 2019). Semua bagian dari tanaman ini sangat bermanfaat bagi kehidupan masyarakat sehingga dijuluki "miracle tree" (Jusnita \& Syurya, 2019). Berbagai macam olahan kelor pada masyarakat, diantaranya disajikan dalam bentuk makanan dan ramuan obat-obatan seperti jamu. Dalam penelitian reproduksi, kelor dimanfaatkan sebagai Makanan Pendamping ASI, berkhasiat mencegah kanker ovarium, menyembuhkan endometriosis dan penyakit kelamin gonorrhea (Andjani et al., 2017; Antina, 2017; Jusnita \& Syurya, 2019; Lestari, 2018; Rahayu \& Nurindahsari, 2018; Utary et al., 2019; Widowati et al., 2014).

Berdasarkan penelitian terdahulu, diketahui bagian kelor yang paling berkhasiat adalah daun. Daun kelor memiliki nilai gizi cenderung lebih tinggi dari bagian yang lainnya (Nurulita et al., 2019), sehingga ekstrak daun kelor patut diduga dapat meningkatkan ukuran ovarium dan mengoptimalkan fungsi kerjanyanya. Oleh karena itu, diperlukan kajian lebih lanjut mengenai morfometri ovarium setelah pemberian ekstrak daun kelor (Moringa oleifera LAM).

\section{BAHAN DAN METODE}

\section{Rancangan Penelitian}

Metode yang digunakan adalah eksperimental. Rancangan penelitian yang digunakan adalah faktorial rancangan acak lengkap (RAL) dengan 4 perlakuan dan 5 waktu pengamatan. Perlakuan pertama ( $\mathrm{P} 1)$ : pemberian ekstrak daun kelor dosis 0 $\mathrm{mg} \mathrm{kg}^{-1} \mathrm{BB}$ mencit (kontrol) yang diberikan pelarut ekstrak daun kelor (CMC 0.2\%). P2: pemberian ekstrak daun kelor dosis $300 \mathrm{mg} \mathrm{kg}^{-1} \mathrm{BB}$ mencit. $\mathrm{P} 3$ : yaitu pemberian ekstrak daun kelor dosis $400 \mathrm{mg}$ $\mathrm{kg}^{-1}$ BB mencit. P4: pemberian ekstrak daun kelor dosis $500 \mathrm{mg} \mathrm{kg}^{-1} \mathrm{BB}$ mencit. Pengamatan dilakukan setelah pemberian $5,10,15,24$, dan 34 hari. Setiap pengamatan diambil tiga ekor mencit dari setiap perlakuan untuk mengamati morfometri ovarium.

\section{Persiapan Hewan Uji}

Hewan yang digunakan adalah 60 ekor mencit induk (Mus musculus) umur 14-15 minggu dengan rerata bobot badan 25-35 g. Mencit diperoleh dari Laboratorium Farmasi UHO yang diadaptasikan selama dua minggu. Mencit dipelihara secara kelompok (lima ekor mencit/ kandang). Kandang berbentuk segi empat ukuran $38 \mathrm{~cm} \times 27 \mathrm{~cm} \times 13 \mathrm{~cm}$ yang ditutupi kawat. Bedding pada kandang berupa serutan kayu yang diganti dua kali seminggu. Selama pemeliharaan pakan diberikan $5 \mathrm{~g} /$ hari berupa pellet yang dibagi menjadi dua kali pemberian yaitu pagi dan sore hari. Air minum diberikan secara ad libitum melalui botol minum.

\section{Pembuatan Ekstrak Daun Kelor}

Ekstraksi dilakukan dengan metode perendaman (maserasi). Sebanyak $1000 \mathrm{~g}$ simplisia daun kelor dilarutkan dalam wadah berisi 3 L etanol 96\% (nisbah 1:3) b/v). Campuran tersebut diaduk secara manual selama \pm 30 menit, kemudian didiamkan selama 24 jam pada suhu ruang. Penyaringan dilakukan menggunakan kain flanel dan kertas saring. Prosedur yang sama diulangi sampai diperoleh larutan ekstrak kelor yang tampak bening. Filtrat dari penyaringan digabung dan dipekatkan menggunakan rotavapor pada suhu $40^{\circ} \mathrm{C}$.

\section{Kajian Siklus Estrus Mencit Berdasarkan Gambaran Sel Ulas Vagina}

Pengamatan terhadap siklus estrus dilakukan untuk mengetahui bahwa siklus reproduksi dalam ovarium mencit berlangsung normal. Kegiatan ini dimulai dari hari pertama ( $\left.\mathrm{H}_{1}\right)$ sampai hari pengambilan ovarium yaitu setelah hari ke-5, 10, 15, 24 dan 34. Ulas vagina dilakukan menggunakan cotton bud and $\mathrm{NaCl}$ fisiologis yang diulas 3-5 kali, selanjutnya diulas pada gelas obyektif, kemudian diwarnai dengan giemsa, prerapat diamati di bawah mikroskop dengan perbesaran obyektif 10 dan 40 kali. Pada ulas vagina ditentukan fase yang sedang dialami hewan coba melalui tipe sel, proporsi masing-masing sel, dan keberadaan leukosit. 
46 | Balumbi et al.

\section{HASIL}

Lama Pemberian dan Konsentrasi Ekstrak Daun Kelor terhadap Panjang Ovarium Mencit

Lama pemberian dan konsentrasi ekstrak daun kelor terhadap panjang ovarium mencit disajikaan pada Tabel 1. Tabel tersebut memperlihatkan konsentrasi dan lama pemberian ekstrak daun kelor berpengaruh terhadap panjang ovarium mencit. Hal ini dibuktikan dengan nilai signifikansi yang diperoleh sebesar $<0.05$.

Uji lanjut pengaruh konsentrasi ekstrak daun kelor terhadap panjang ovarium mencit disajikan pada Tabel 2. Lama pemberian ekstrak daun kelor terhadap panjang ovarium mencit disajikan pada Gambar 1. Gambar 1 memperlihatkan lama pemberian ekstrak daun kelor berpengaruh terhadap panjang ovarium mencit. Dari grafik tersebut, pembedahan mencit $\mathrm{H}_{5}$ diperoleh rerata panjang ovarium pada kelompok $\mathrm{P}_{1}=0,17 \mathrm{~cm}, \mathrm{P}_{2}=0,22 \mathrm{~cm}, \mathrm{P}_{3}=$ $0,27 \mathrm{~cm}$, dan $\mathrm{P} 4=0,3 \mathrm{~cm}$. Pembedahan mencit $\mathrm{H} 10$ diperoleh rerata panjang ovarium pada kelompok $\mathrm{P}_{1}=0.17 \mathrm{~cm}, \mathrm{P}_{2}=0,12 \mathrm{~cm}, \mathrm{P}_{3}=0,22 \mathrm{~cm}$ dan $\mathrm{P}_{4}=0,32$ $\mathrm{cm}$. Pada pembedahan mencit $\mathrm{H} 15$ diperoleh rerata panjang ovarium pada kelompok $\mathrm{P}_{1}=0,27 \mathrm{~cm}, \mathrm{P}_{2}=$ $0,33 \mathrm{~cm}, \mathrm{P}_{3}=0,33 \mathrm{~cm}$, dan $\mathrm{P}_{4}=0,41 \mathrm{~cm}$. Pembedahan mencit $\mathrm{H} 24$ diperoleh rerata panjang ovarium pada kelompok $\mathrm{P}_{1}=0,25 \mathrm{~cm}, \mathrm{P}_{2}=0,28 \mathrm{~cm}, \mathrm{P}_{3}=0,3 \mathrm{~cm}$, dan $\mathrm{P}_{4}=0,35 \mathrm{~cm}$. Pembedahan mencit hari terakhir (H34) diperoleh rerata panjang ovarium pada kelompok $\mathrm{P}_{1}=0,22 \mathrm{~cm}, \mathrm{P}_{2}=0,33 \mathrm{~cm}, \mathrm{P}_{3}=0,37 \mathrm{~cm}$, dan $\mathrm{P}_{4}=0,37 \mathrm{~cm}$.

Uji lanjut pengaruh lamanya perlakuan pemberian ekstrak daun kelor terhadap panjang ovarium mencit disajikan pada Tabel 3. Hasil uji lanjut dengan menggunakan analisis Duncan, menunjukan lamanya perlakuan terhadap panjang ovarium mencit pada kelompok $\mathrm{H}_{5}$ dan $\mathrm{H} 10$ tidak ada perbedaan signifikan, hal ini juga terjadi pada kelompok H15, H24 dan H34. Namun perbedaan signifikan terjadi pada kelompok perlakuan $\mathrm{H}_{5}$ dan $\mathrm{H} 10$ dengan kelompok $\mathrm{H} 15, \mathrm{H} 24$, dan $\mathrm{H}_{34}$.

\section{Lama Pemberian dan Konsentrasi Ekstrak Daun Kelor terhadap Lebar Ovarium Mencit}

Lama pemberian dan konsentrasi ekstrak daun kelor terhadap lebar ovarium mencit dapat dilihat pada Tabel 4. Tabel 4 memperlihatkan konsentrasi dan lama pemberian ekstrak daun kelor berpengaruh terhadap lebar ovarium mencit. Hal ini dibuktikan dengan nilai signifikansi yang diperoleh sebesar < 0.05. Uji lanjut pengaruh konsentrasi ekstrak daun kelor terhadap lebar ovarium mencit disajikan pada Tabel 5. Tabel 5 menunjukan tingkat konsentrasi ekstrak daun kelor berpengaruh terhadap lebar ovarium mencit. Namun, pada konsentrasi

Tabel 1 Lama pemberian dan konsentrasi ekstrak daun kelor terhadap panjang ovarium mencit

\begin{tabular}{cccccc}
\hline Source & $\begin{array}{c}\text { Type III Sum of } \\
\text { Squares }\end{array}$ & df & Mean Square & F & Sig. \\
\hline Corrected Model & $.279^{\mathrm{a}}$ & 19 & .015 & 6.785 & .000 \\
Intercept & 4.704 & 1 & 4.704 & 2171.077 & .000 \\
H & .122 & 4 & .030 & 14.058 & .000 \\
$\mathrm{P}$ & .134 & 3 & .045 & 20.564 & .000 \\
$\mathrm{H}^{*} \mathrm{P}$ & .024 & 12 & .002 & .917 & .540 \\
Error & .087 & 40 & .002 & & \\
Total & 5.070 & 60 & & & \\
Corrected Total & .366 & 59 & & & \\
\hline
\end{tabular}

Tabel 2 Uji lanjut pengaruh konsentrasi ekstrak daun kelor terhadap panjang ovarium mencit

\begin{tabular}{cccccc}
\hline & Perlakuan P & N & \multicolumn{3}{c}{ Subset } \\
\cline { 3 - 5 } Duncan $^{\mathrm{a}, \mathrm{b}}$ & $\mathrm{P} 1$ & 15 & $\mathbf{1}$ & $\mathbf{2}$ & $\mathbf{3}$ \\
& $\mathrm{P} 2$ & 15 & & .2667 & \\
& P3 & 15 & & .2967 & \\
& P4 & 15 & & & .3433 \\
& Sig. & & 1.000 & .085 & 1.000 \\
\hline
\end{tabular}




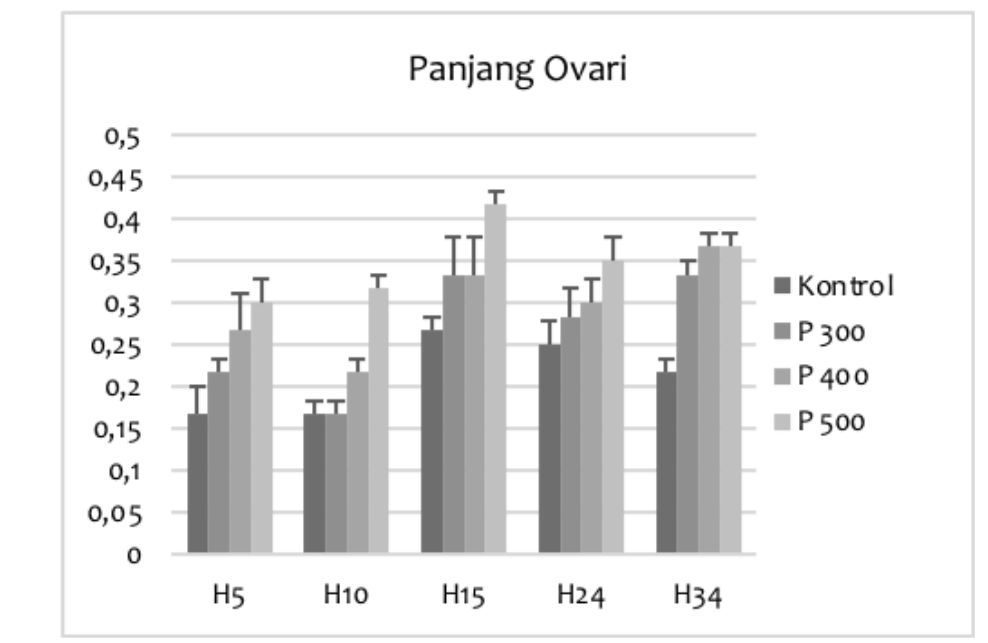

Keterangan: $\mathrm{H}_{5}-\mathrm{H}_{3} 4=$ Hari ke 5 -Hari ke $34 ;$ Kontrol= $\mathrm{P}_{1} ; \mathrm{P}_{300}=\mathrm{P}_{2} ; \mathrm{P} 400=\mathrm{P}_{3} ; \mathrm{P}_{500}=\mathrm{P}_{4}$

Gambar 1 Grafik lama pemberian ekstak daun kelor terhadap panjang ovarium mencit

Tabel 3 Uji lanjut pengaruh lamanya perlakuan pemberian ekstrak daun kelor terhadap panjang ovarium mencit

\begin{tabular}{ccccc}
\hline & Perlakuan H & N & \multicolumn{2}{c}{ Subset } \\
\cline { 3 - 5 } & $\mathrm{H} 10$ & 12 & .2167 & $\mathbf{2}$ \\
\hline \multirow{4}{*}{ Duncan $^{\mathrm{a}, \mathrm{b}}$} & $\mathrm{H} 5$ & 12 & .2375 & \\
& $\mathrm{H} 24$ & 12 & & .2958 \\
& $\mathrm{H} 34$ & 12 & & .3208 \\
& $\mathrm{H} 15$ & 12 & & .3292 \\
& Sig. & & .279 & .105 \\
\hline
\end{tabular}

Tabel 4 Lama pemberian dan konsentrasi ekstrak daun kelor terhadap lebar ovarium mencit

\begin{tabular}{cccccc}
\hline Source & $\begin{array}{c}\text { Type III Sum of } \\
\text { Squares }\end{array}$ & df & Mean Square & F & Sig. \\
\hline Corrected Model & $.261^{\mathrm{a}}$ & 19 & .014 & 11.368 & .000 \\
Intercept & 2.481 & 1 & 2.481 & 2052.966 & .000 \\
H & .186 & 4 & .046 & 38.397 & .000 \\
P & .061 & 3 & .020 & 16.828 & .000 \\
H P & .014 & 12 & .001 & .994 & .471 \\
Error & .048 & 40 & .001 & & \\
Total & 2.790 & 60 & & & \\
Corrected Total & .309 & 59 & & & \\
\hline
\end{tabular}

$300 \mathrm{mg} / \mathrm{kg}$ BB dan $400 \mathrm{mg} / \mathrm{kg}$ BB tidak terjadi perbedaan signifikan.

Lama pemberian ekstak daun kelor terhadap lebar ovarium mencit dapat dilihat pada Gambar 2. Gambar ini memperlihatkan lama pemberian ekstrak daun kelor berpengaruh terhadap lebar ovarium mencit. Dari grafik tersebut, pembedahan mencit $\mathrm{H}_{5}$ diperoleh rerata lebar ovarium pada kelom- pok $\mathrm{P}_{1}=0,10 \mathrm{~cm}, \mathrm{P}_{2}=0,12 \mathrm{~cm}, \mathrm{P}_{3}=0,17 \mathrm{~cm}$, dan $\mathrm{P}_{4}=$ $0,22 \mathrm{~cm}$. Pembedahan mencit $\mathrm{H} 10$ diperoleh rerata lebar ovarium pada kelompok $\mathrm{P}_{1}=0,10 \mathrm{~cm}, \mathrm{P}_{2}=$ $0,13 \mathrm{~cm}, \mathrm{P}_{3}=0,10 \mathrm{~cm}$, dan $\mathrm{P}_{4}=0,16 \mathrm{~cm}$. Pada pembedahan mencit $\mathrm{H} 15$ diperoleh rerata lebar ovarium pada kelompok $\mathrm{P}_{1}=0,20 \mathrm{~cm}, \mathrm{P}_{2}=0,27 \mathrm{~cm}, \mathrm{P}_{3}=$ $0,27 \mathrm{~cm}$, dan $\mathrm{P}_{4}=0,33 \mathrm{~cm}$. 
48 | Balumbi et al.

Tabel 5 Uji lanjut pengaruh konsentrasi ekstrak daun kelor terhadap lebar ovarium mencit

\begin{tabular}{|c|c|c|c|c|c|}
\hline & \multirow{2}{*}{ Perlakuan $\mathrm{P}$} & \multirow{2}{*}{$\mathbf{N}$} & \multicolumn{3}{|c|}{ Subset } \\
\hline & & & 1 & 2 & 3 \\
\hline \multirow{5}{*}{ Duncan ${ }^{\mathrm{a}, \mathrm{b}}$} & P1 & 15 & .1600 & & \\
\hline & $\mathrm{P} 2$ & 15 & & .2000 & \\
\hline & $P_{3}$ & 15 & & .2033 & \\
\hline & P4 & 15 & & & .2500 \\
\hline & Sig. & & 1.000 & .794 & 1.000 \\
\hline
\end{tabular}

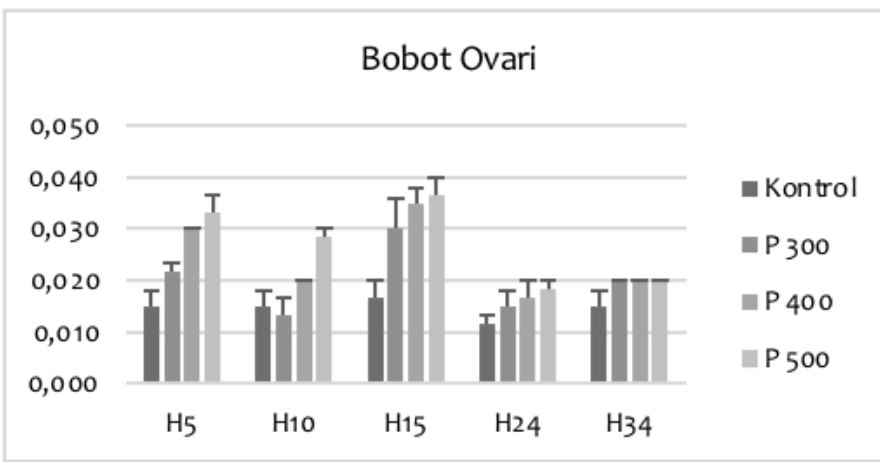

Keterangan: $\mathrm{H}_{5}-\mathrm{H}_{3} 4=$ Hari ke 5 -Hari ke 34; Kontrol= $\mathrm{P}_{1} ; \mathrm{P}_{300}=\mathrm{P}_{2} ; \mathrm{P}_{400}=\mathrm{P}_{3} ; \mathrm{P}_{500}=\mathrm{P}_{4}$ Gambar 2 Grafik lama pemberian ekstak daun kelor terhadap lebar ovarium mencit

Pembedahan mencit $\mathrm{H} 24$ diperoleh rerata lebar ovarium pada kelompok $\mathrm{P}_{1}=0,20 \mathrm{~cm}, \mathrm{P}_{2}=0,23 \mathrm{~cm}$, $\mathrm{P}_{3}=0,23 \mathrm{~cm}$, dan $\mathrm{P}_{4}=0,25 \mathrm{~cm}$. Pembedahan mencit hari terakhir $(\mathrm{H} 34)$ diperoleh rerata lebar ovarium pada kelompok $\mathrm{P}_{1}=0,20 \mathrm{~cm}, \mathrm{P}_{2}=0,25 \mathrm{~cm}, \mathrm{P}_{3}=0,25$ $\mathrm{cm}$, dan $\mathrm{P}_{4}=0,28 \mathrm{~cm}$.

Uji lanjut pengaruh lamanya perlakuan pemberian ekstrak daun kelor terhadap lebar ovarium mencit dapat dilihat pada Tabel 6. Hasil uji lanjut dengan menggunakan analisis Duncan, menunjukan lamanya perlakuan terhadap lebar ovarium mencit pada kelompok $\mathrm{H}_{5}$ dan $\mathrm{H} 10$ tidak ada perbedaan signifikan, hal ini juga terjadi pada kelompok H15 dan $\mathrm{H}_{34}$, serta $\mathrm{H}_{24}$ dan $\mathrm{H}_{34}$. Namun perbedaan signifikan terjadi pada kelompok perlakuan $\mathrm{H}_{5}$ dan $\mathrm{H}_{10}$ dengan kelompok $\mathrm{H} 15$, dan $\mathrm{H} 34$, serta kelompok $\mathrm{H} 24$ dan $\mathrm{H}_{34}$.

\section{Lama Pemberian dan Konsentrasi Ekstrak Daun Kelor terhadap Bobot Ovarium Mencit}

Lama pemberian dan konsentrasi ekstrak daun kelor terhadap bobot ovarium mencit dapat dilihat pada Tabel 7. Tabel 7 memperlihatkan konsentrasi dan lama pemberian ekstrak daun kelor berpengaruh terhadap bobot ovarium mencit. Hal ini dibuktikan dengan nilai signifikansi yang diperoleh sebesar $<0.05$.
Uji lanjut pengaruh konsentrasi ekstrak daun kelor terhadap bobot ovarium mencit disajikan pada Tabel 8 . Tabel 8 menunjukkan tingkat konsentrasi ekstrak daun kelor berpengaruh terhadap bobot ovarium mencit. Namun, pada konsentrasi $300 \mathrm{mg} / \mathrm{kg}$ BB dan $400 \mathrm{mg} / \mathrm{kg}$ BB tidak terjadi perbedaan signifikan.

Lama pemberian ekstak daun kelor terhadap bobot ovarium mencit dapat dilihat pada Gambar 3. Gambar 3 memperlihatkan lama pemberian ekstrak daun kelor berpengaruh terhadap lebar ovarium mencit. Dari grafik tersebut, pembedahan mencit $\mathrm{H}_{5}$ diperoleh rerata bobot ovarium pada kelompok $\mathrm{P}_{1}=0,015 \mathrm{~cm}, \mathrm{P}_{2}=0,022 \mathrm{~cm}$, $\mathrm{P}_{3}=0,030 \mathrm{~cm}$, dan $\mathrm{P}_{4}=0,033 \mathrm{~cm}$. Pembedahan mencit $\mathrm{H} 10$ diperoleh rerata bobot ovarium pada kelompok $\mathrm{P}_{1}=0,015 \mathrm{~cm}, \mathrm{P}_{2}=0,013 \mathrm{~cm}, \mathrm{P}_{3}=0,020$ $\mathrm{cm}$, dan $\mathrm{P}_{4}=0,028 \mathrm{~cm}$.

Pembedahan mencit $\mathrm{H} 15$ diperoleh rerata bobot ovarium pada kelompok $\mathrm{P}_{1}=0,017 \mathrm{~cm}, \mathrm{P}_{2}=$ $0,030 \mathrm{~cm}, \mathrm{P}_{3}=0,035 \mathrm{~cm}$, dan $\mathrm{P}_{4}=0,037 \mathrm{~cm}$. Pada pembedahan mencit $\mathrm{H}_{2} 4$ diperoleh rerata bobot ovarium pada kelompok $\mathrm{P}_{1}=0,012 \mathrm{~cm}, \mathrm{P}_{2}=0,015$ $\mathrm{cm}, \mathrm{P}_{3}=0,017 \mathrm{~cm}$, dan $\mathrm{P}_{4}=0,018 \mathrm{~cm}$. Pembedahan mencit hari terakhir $\left(\mathrm{H}_{34}\right)$ diperoleh rerata bobot ovarium pada kelompok $\mathrm{P}_{1}=0,015 \mathrm{~cm}, \mathrm{P}_{2}=0,020$ $\mathrm{cm}, \mathrm{P}_{3}=0,020, \mathrm{~cm}$ dan $\mathrm{P}_{4}=0,020 \mathrm{~cm}$. 
Tabel 6 Uji lanjut pengaruh lamanya perlakuan pemberian ekstrak daun kelor terhadap lebar ovarium mencit

\begin{tabular}{cccccc}
\hline & Perlakuan $\mathbf{H}$ & $\mathbf{N}$ & \multicolumn{3}{c}{ Subset } \\
\cline { 3 - 6 } & $\mathrm{H} 10$ & 12 & $\mathbf{1}$ & $\mathbf{2}$ & $\mathbf{3}$ \\
\hline \multirow{4}{*}{ Duncan $^{\mathrm{a}, \mathrm{b}}$} & $\mathrm{H} 5$ & 12 & .1250 & & \\
& $\mathrm{H} 24$ & 12 & .1500 & .2292 & \\
& $\mathrm{H} 34$ & 12 & & .2458 & .2458 \\
& $\mathrm{H} 15$ & 12 & & .2667 \\
& Sig. & & .086 & .247 & .150 \\
\hline
\end{tabular}

Tabel 7 Lama pemberian dan konsentrasi ekstrak daun kelor terhadap bobot ovarium mencit

\begin{tabular}{cccccc}
\hline Source & $\begin{array}{c}\text { Type III Sum of } \\
\text { Squares }\end{array}$ & df & Mean Square & F & Sig. \\
\hline Corrected Model & $.261^{\mathrm{a}}$ & 19 & .014 & 11.368 & .000 \\
Intercept & 2.481 & 1 & 2.481 & 2052.966 & .000 \\
H & .186 & 4 & .046 & 38.397 & .000 \\
P & .061 & 3 & .020 & 16.828 & .000 \\
H $^{*}$ & .014 & 12 & .001 & .994 & .471 \\
Error & .048 & 40 & .001 & & \\
Total & 2.790 & 60 & & & \\
Corrected Total & .309 & 59 & & & \\
\hline
\end{tabular}

Tabel 8 Uji lanjut pengaruh konsentrasi ekstrak daun kelor terhadap bobot ovarium mencit

\begin{tabular}{|c|c|c|c|c|c|}
\hline & \multirow{2}{*}{ Perlakuan P } & \multirow{2}{*}{$\mathbf{N}$} & \multicolumn{3}{|c|}{ Subset } \\
\hline & & & 1 & 2 & 3 \\
\hline \multirow{5}{*}{ Duncanna,b } & $\mathrm{P} 1$ & 15 & .1600 & & \\
\hline & $\mathrm{P}_{2}$ & 15 & & 2000. & \\
\hline & $\mathrm{P}_{3}$ & 15 & & .2033 & \\
\hline & $\mathrm{P} 4$ & 15 & & & .2500 \\
\hline & Sig. & & 1.000 & .794 & 1.000 \\
\hline
\end{tabular}

Uji lanjut pengaruh lamanya perlakuan pemberian ekstrak daun kelor terhadap bobot ovarium mencit dapat dilihat pada Tabel 9. Hasil uji lanjut dengan menggunakan analisis Duncan, menunjukan lamanya perlakuan terhadap bobot ovarium mencit padakelompok $\mathrm{H}_{5}$ dan $\mathrm{H} 10$ tidak ada perbedaan signifikan, hal ini juga terjadi pada kelompok $\mathrm{H} 15$ dan $\mathrm{H}_{34}$, serta $\mathrm{H}_{24}$ dan H34. Namun perbedaan signifikan terjadi pada kelompok perlakuan $\mathrm{H}_{5}$ dan $\mathrm{H}_{10}$ dengan kelompok $\mathrm{H}_{15}$ dan $\mathrm{H}_{34}$, serta kelompok $\mathrm{H}_{24}$ dan $\mathrm{H} 34$.

\section{Siklus Estrus}

Hasil pengamatan siklus estrus dengan vaginal smear, dari 60 ekor mencit tidak menunjukan perbe- daan signifikan lamanya siklus estrus. Secara umum, panjang siklus estrus kelompok kontrol maupun kelompok perlakuan berkisar antara 4-5 hari.

\section{PEMBAHASAN}

Tingkat Konsentrasi dan Lamanya Pemberian Ekstrak Daun Kelor Terhadap Morfometri Ovarium

Hasil penelitian menunjukkan bahwa tingkat konsentrasi dan lamanya pemberian ekstrak daun kelor memberi pengaruh terhadap panjang, lebar, dan bobot ovarium mencit. Hal ini diduga disebabkan oleh kandungan kimia seperti vitamin, flavonoid, alkaloid, fenol, saponin, tanin, tripenoid/ steroid (Anwar et al., 2007; Kasolo et al., 2010; Putra et al., 2016; Sutrisno, 2011; Wulan et al., 2019). 


\section{Lebar Ovari}

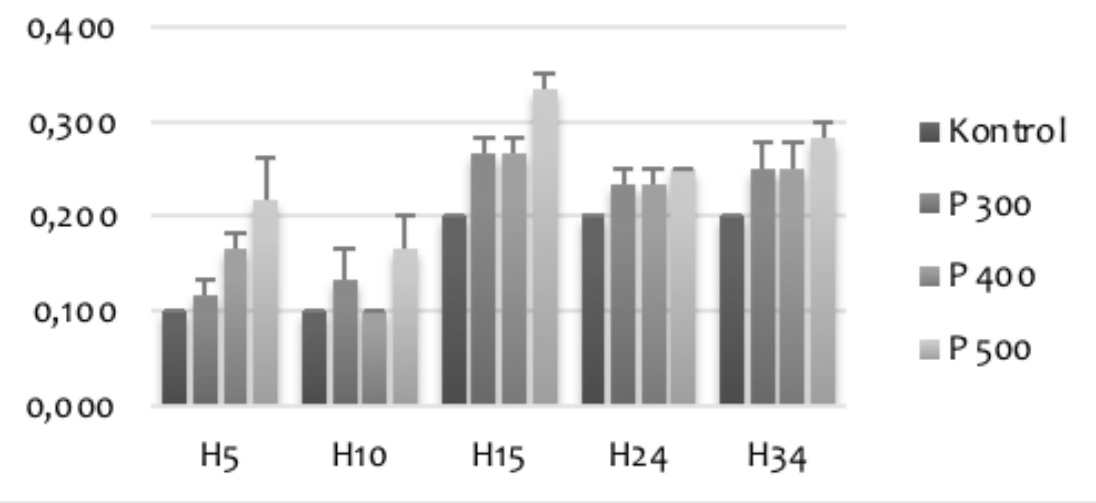

Keterangan: $\mathrm{H}_{5}-\mathrm{H}_{34}=$ Hari ke 5-Hari ke 34; Kontrol= $\mathrm{P}_{1} ; \mathrm{P}_{300}=\mathrm{P}_{2} ; \mathrm{P}_{400}=\mathrm{P}_{3} ; \mathrm{P}_{500}=\mathrm{P}_{4}$ Gambar 3 Grafik lama pemberian ekstak daun kelor terhadap bobot ovarium mencit

Tabel 9 Uji lanjut pengaruh lamanya perlakuan pemberian ekstrak daun kelor terhadap bobot ovarium mencit

\begin{tabular}{cccccc}
\hline & Perlakuan H & N & \multicolumn{3}{c}{ Subset } \\
\cline { 3 - 5 } & & & $\mathbf{1}$ & $\mathbf{2}$ & $\mathbf{3}$ \\
\hline \multirow{3}{*}{ Duncan $^{\mathrm{a}, \mathrm{b}}{ }^{\mathrm{b}}$} & $\mathrm{H} 10$ & 12 & .1250 & & \\
& $\mathrm{H} 5$ & 12 & .1500 & & \\
& $\mathrm{H} 24$ & 12 & & .2292 & .2458 \\
& $\mathrm{H} 34$ & 12 & & .2458 & .2667 \\
& $\mathrm{H} 15$ & 12 & & .247 & .150 \\
\hline
\end{tabular}

Salah satu yang paling menonjol yang diduga memberi efek besar terhadap ukuran dan bobot ovarium dari kandungan daun kelor adalah flavonoid yang tinggi (Andjani et al., 2017). Pada tumbuhan, flavonoid berfungsi sangat penting dalam menunjang proses fotosintesis, anti mikroba, dan antivirus (Robinson, 1995). Flavonoid merupakan kelompok senyawa isoflavon yang dapat berikatan langsung dengan reseptor esterogen, karena memiliki struktur kimia yang mirip dengan $17-\alpha$ estradiol dalam tubuh (Russel et al., 2000).

Kandungan menonjol lainnya pada ekstrak daun kelor adalah steroid. Steroid masuk ke dalam kelompok fitosterol yang tidak dapat berikatan langsung dengan reseptor estrogen, sehingga perlu disintesis lagi dengan bantuan enzim tertentu yang dihasilkan oleh mitokondria dan retikulum endoplasma halus untuk mendapatkan struktur kimia yang mirip dengan 17-a estradiol (Cheng et al., 2002; Russel et al., 2000).

Kandungan flavonoid dan steroid yang terdapat pada ekstrak daun kelor merupakan bagian dari fitoestrogen yang memiliki aktivitas hampir sama dengan hormon estrogen endogen, sehingga mampu mengenali dan berikatan dengan reseptor esterogen dalam organ tubuh yang berada di membran nukleus dan membran plasma (Mahmudati, 2011). Reseptor esterogen dalam tubuh terbagi menjadi dua jenis yaitu reseptor esterogen alpha (ER- $\alpha$ ) dan reseptor esterogen beta (ER- $\beta$ ). ER- $\alpha$ terdapat di sejumlah organ target salah satunya ovarium dan uterus, sedangkan ER- $\beta$ terdapat pada organ ovarium, hipotalamus, paru-paru, dan ginjal (Lusiana, 2017; Satyaningtijas et al., 2014).

Asupan senyawa fitoestrogen dari ekstrak daun kelor pada mencit diduga membantu mengisi kekosongan reseptor estrogen yang belum berikatan dengan estrogen dalam tubuh, sehingga kadar estrogen dalam darah meningkat dan merangsang hipotalamus mensekresikan GnRF (Gonadotropin Releasing Factor) agar hipofisis anterior memperbanyak mensekresikan hormon FSH untuk menstimulasi folikel primer menjadi de Graff (Russel et al., 2000). Selain itu, Tingginya kadar estrogen dalam darah menyebabkan lonjakan LH (luteinizing hormone) dalam darah, kondisi ini menyebabkan 
proliferasi sel-sel di dalam ovarium sehingga menyebabkan ukuran dan berat ovarium bertambah (Sanchez et al., 2014).

\section{Siklus Estrus}

Konfirmasi siklus estrus adalah bagian dari penelitian yang tujuannya untuk mengetahui bahwa siklus reproduksi dalam ovarium mencit berlangsung normal. Siklus estrus pada mencit normalnya terjadi selama 4-5 hari (Sjahfirdi et al., 2013). Secara umum, terlihat bahwa siklus estrus pada mencit penelitian berlangsung selama 4-5 hari.

Siklus estrus pada mencit terdiri dari 4 fase utama, yaitu proestrus, estrus, metestrus dan diestrus. Fase proestrus ditandai dengan ditemukannya sejumlah sel primordial, small intermediet, dan large intermediet. Fase estrus ditandai peningkatan sel-sel superfisial. Fase metestrus ditandai dengan ditemukannya sel leukosit yang menggelilingi sel superfisial. Sedangkan fase diestrus ditandai dengan muculnya sel primordial dan masih ditemukan adanya sel leukosit. Berdasarkan hasil vaginal smear mencit yang diberi ektrak daun kelor dengan konsentrasi berbeda menunjukan lama siklus estrus tidak berbeda nyata. Dari data terlihat dengan panjang siklus estrus mencit tiap kelompok berkisar antara 45 hari. Smith \& Mangkoewidjojo (1988) menyatakan bahwa siklus normal mencit berkisar antara 4-5 hari. Hal ini menunjukan bahwa ekstrak daun kelor tidak memberikan efek yang menghambat siklus estrus mencit. Penelitian yang dilakukan oleh Amelia et al (2017) membuktikan bahwa ektrak daun kelor dapat meningkatkan jumlah folikel pada mencit yang mengalami Polycystic Ovary Syndrome (PCOS), sehingga dapat memperbaiki siklus reproduksi mencit tersebut.

\section{"Penulis menyatakan tidak ada konflik kepentingan dengan pihak-pihak yang terkait dalam penelitian ini".}

\section{DAFTAR PUSTAKA}

Amelia D, Santoso B, Purwanto B. 2017. Ekstrak daun Moringa oleifera terhadap jumlah folikel tikus model sindroma ovarium polikistik. Jurnal Biosains Pascasarjana 19(3): 211-223.

Andjani N, Sujuti H, Winarsih S. 2017. Efek ekstrak etanol daun kelor (Moringa oleifera) terhadap nuclear factor kappa beta (NF-kB) aktif dan apoptosis cell line kanker MCF-7. Majalah Kesehatan FKUB 3(4): 204-212.
Antina RR. 2017. Ekstrak etanol Moringa Oleifera Lam terhadap folikulogenesis pada mencit model endometriosis. Jurnal Biosains Pascasarjana 19(3): 246-259.

Anwar F, Latif S, Ashraf M, Gilani AH. 2007. Moringa oleifera: a food plant with multiple medicinal uses. Phytotherapy Research: An International Journal Devoted to Pharmacological and Toxicological Evaluation of Natural Product Derivatives 21(1): 17-25.

Balumbi M, Supriatna I, Setiadi MA. 2019. Respons dan karakteristik estrus setelah sinkronisasi estrus dengan cloprostenol pada sapi Friesian Holstein. Acta Veterinaria Indonesiana 7(1): 29-36.

Chavatte-Palmer P, Dupont C, Debus N, Camous S. 2014. Nutritional programming and the reproductive function of the offspring. Animal Production Science 54(9): 1166-1176.

Cheng G, Weihua Z, Mäkinen S, Mäkelä S, Saji S, Warner M, Hovatta O. 2002. A role for the androgen receptor in follicular atresia of estrogen receptor beta knockout mouse ovary. Biology of reproduction 66(1): 77-84.

Gannon AM, Stämpfli MR, Foster WG. 2012. Cigarette smoke exposure leads to follicle loss via an alternative ovarian cell death pathway in a mouse model. Toxicological Sciences 125(1): 274-284.

Gannon AM, Stämpfli MR, Foster WG. 2013. Cigarette smoke exposure elicits increased autophagy and dysregulation of mitochondrial dynamics in murine granulosa cells. Biology of reproduction 88(3): 63-71.

Jusnita N, Syurya W. 2019. Karakterisasi nanoemulsi ekstrak daun kelor (Moringa oleifera Lamk.). Jurnal Sains Farmasi \& Klinis 6(1): 16-24.

Kasolo JN, Bimenya GS, Ojok L, Ochieng J, OgwalOkeng JW. 2010. Phytochemicals and uses of Moringa oleifera leaves in Ugandan rural communities. Journal of Medicinal Plants Research 4(9): 753-757.

Lestari YD. 2018. Pengaruh ekstrak etanol daun kelor (Moringa oleifera Lam.) terhadap apoptosis sel granulosa pada mencit (Mus musculus) model endometriosis. Jurnal Biosains Pascasarjana 20(1): 1-8.

Lusiana N. 2017. Pengaruh fitoestrogen daging buah kurma ruthab (Phoenix dactylifera I.) Terhadap sinkronisasi siklus estrus mencit (Mus musculus I.) Betina. Klorofil: Jurnal Ilmu Biologi dan Terapan 1(1): 24-31.

Mahmudati N. 2011. Kajian biologi molekuler peran estrogen/fitoestrogen pada metabolisme tulang 
usia menopause. In Proceeding Biology Education Conference: Biology, Science, Enviromental, and Learning 8(1): 421-430.

Nurulita NA, Sundhani E, Amalia I, Rahmawati F, Utami NND. 2019. Uji aktivitas antioksidan dan anti aging body butter dengan bahan aktif ekstrak daun kelor. Jurnal Ilmu Kefarmasian Indonesia 17(1): 1-8.

Putra IWDP, Dharmayudha AAGO, Sudimartini LM. 2016. Identifikasi senyawa kimia ekstrak etanol daun kelor (Moringa oleifera L) di Bali. Indonesia Medicus Veterinus 5(5): 464-473.

Rahayu TB, Nurindahsari YAW. 2018. Peningkatan status gizi balita melalui pemberian daun kelor (Moringa oleifera). Jurnal Kesehat Madani Medika 9(2): 87-91.

Ramadhani SA, Supriatna I, Karja NWK, Winarto A. 2017. Pengendalian folikulogenesis ovarium dengan pemberian ekstrak biji kapas. Jurnal Sains Veteriner 35(1): 71-80.

Robinson T. 1995. Kandungan Organik Tumbuhan Tinggi. ITB Press. Jakarta. p1-6.

Russell KS, Haynes MP, Sinha D, Clerisme E, Bender JR. 2000. Human vascular endothelial cells contain membrane binding sites for estradiol, which mediate rapid intracellular signaling. Proceedings of the National Academy of Sciences 97(11): 5930-5935.

Sanchez AM, Viganò $P$, Somigliana $E$, PaninaBordignon P, Vercellini P, Candiani M. 2014. The distinguishing cellular and molecular features of the endometriotic ovarian cyst: from pathophysiology to the potential endometriomamediated damage to the ovary. Human Reproduction Update 20(2): 217-230.
Satyaningtijas AS, Maheshwari H, Achmadi P, Pribadi WA, Hapsari S, Jondriatno D, Kiranadi B. 2014. Kinerja reproduksi tikus bunting akibat pemberian ekstrak etanol purwocen. Jurnal Kedokteran Hewan-Indonesian Journal of Veterinary Sciences 8(1): 35-37.

Sjahfirdi L, Astuti P, Maheshwari H. 2013. Pemeriksaan profil hormon progesteron selama siklus estrus tikus (Rattus norvegicus) Betina Menggunakan Perangkat Inframerah. Jurnal Kedokteran Hewan-Indonesian Journal of Veterinary Sciences 7(1): 32-36.

Smith JB, Mangkoewidjojo S. 1988. Pemeliharaan, Pembiakan dan Penggunaan Hewan Percobaan di Daerah Tropis. Universitas Indonesia. Jakarta.

Sutrisno L. 2011. Efek Pemberian Ekstrak Methanol Daun Kelor (Moringa oleifera) Meningkatkan Apoptosis pada Sel Epitel Kolon Tikus (Rattus Norvegius) Wistar yang diinduksi 7, 12 Dimetilbenz (A) Antrasen (DMBA). Skripsi S1. Universitas Brawijaya, Malang.

Utary N, Murti K, Septadina IS. 2019. Effects of Moringa (Moringa oleifera) leaf extract on alveolar diameter of breastfeeding and weight of infant Wistar rats. Journal of Physics: Conference Series 1246(1): 1-8.

Widowati L, Winarno MW, Intan PR. 2014. Toksisitas akut dan subkronis ramuan ekstrak kelor dan klabet sebagai pelancar ASI dan penambah gizi. Jurnal Kefarmasian Indonesia 4(2): 51-64.

Wulan AH, Sholeh SN, Wigati D. 2019. Pengaruh pemberian fraksi etil asetat daun kelor (Moringa oleifera LAM.) Terhadap gambaran histopatologi dan kadar SGPT dan SGOT pada tikus jantan galur wistar yang induksi monosodium glutamat. Media Farm Indonesia 14(1): 1455-1460. 